\title{
PREFACE TO THE ENGLISH TRANSLATION
}

This is the first part of my study entitled El positivismo en México. It analyzes the antecedents and birth of the philosophy used by the Mexicans after the triumph of the liberal Reform movement led by Benito Juárez. Once colonial conservatism was conquered, the French Intervention over, and Maximilian of Hapsburg executed, the reformers wanted to create a new national order to replace the Spanish colonial one. The victorious liberals immediately tried to achieve what their leaders called "mental emancipation," a kind of second independence, which would abolish the habits and customs imposed on Mexicans by three centuries of colonialism. They expressed the need for a philosophy to replace the one that had introduced into colonial Mexico habits of subordination and servitude.

The Mexican Reform, expression of this liberal ideology, had fulfilled its mission; it had combatted and destroyed the colonial system. A new ideology, one of order rather than combat, was to provide the basis for a new system. As you will later detect in this book, the new system would rest on the philosophy of Auguste Comte. The second part of my study, El apogeo $y$ decadencia del positivismo en México [The apogee and fall of positivism in Mexico], examines this new ideology, which was supported by positivist interpretations of John Stuart Mill, Herbert Spencer, and Charles Darwin. It was necessarily a provocative ideology, inasmuch as it justified the domination and exploitation of marginal social groups-a domination and exploitation in no way different from that imposed by the former colony-on the basis of a supposedly scientific language. 
The Comtian motto, Order and Progress, adopted by the social group that Justo Sierra called the "Mexican Bourgeoisie," merely served to maintain colonial forms of exploitation and, at the same time, to create new ones that were peculiar to the neocolonialism that the great nations of western Europe and North America imposed on other peoples. These leaders of progress prevailed upon Mexico to adopt the positivist philosophy. The so-called Mexican bourgeoisie would collaborate in that neocolonialism by accepting the role of intermediary and amanuensis in the new empire. The conflict between exploited social groups, on the one hand, and foreign interests and a middle class on the margin of an oligarchy, on the other, brought about the movement known as the Mexican Revolution. The revolution tried to correct the errors that had prevented the fulfillment of the dreams of the great liberal leaders of the nineteenth century who strived to make Mexico a modern and progressive nation. Their model of progress was the great nations, which, at their height, had given origin to neocolonialism. They wanted Mexico to become a part of modern progress and a Mexican nation rather than a dependency. The present essay describes this experience. The men of the revolution were not going to repeat the errors of Mexican liberalism, which, during the Porfiriato, was transformed into order by the acceptance of a new kind of subordination.

This book, now translated for the English reader, is not unknown to the United States student of Mexico and Latin America. On the contrary, it has received special attention, which includes criticism as well as interpretation. The same applies to the rest of my works that deal with the study of Latin American ideas, thought, and philosophy. Various friends of mine in the United States, including those who have made possible the publication of this work in English under the auspices of the University of Texas Press, suggested that I make special reference to the criticisms and interpretations of this book by United States scholars. Having summarized the contents of the book, I will now mention these interpretations, for which I am grateful, inasmuch as they have stimulated me to continue this work, which has its natural limitations.

I will refer, specifically, to three United States scholars of Latin American and Mexican thought who have been concerned with 
this book and have related it to the rest of my works. They are Professors Harold Eugene Davis of the American University, Charles A. Hale of the University of Iowa, and William D. Raat of Moorhead State College. To begin with, I wish to emphasize a general observation that refers to everything that has not been treated in this book and in my other published works. Naturally, I accept it and-remembering my teacher, José Gaos-I believe that there is no limit to my ignorance, except for what $I$ have already written. Along these lines, the universally known work on Latin American thought by Harold Eugene Davis analyzes certain aspects that were not included in my perspective, but from now on they will be treated by future scholars or by anyone who wishes to learn more about Latin American thought. In addition, Charles A. Hale has written a book on José María Luis Mora, and I understand that he is now writing another book concerning new interpretations of Mexican thought that I did not include in my study of positivism. He will complete, with additions, what I have been expounding. A more persistent and sharper critic is William D. Raat. His work on positivism in Mexico, as I understand it, includes aspects that escaped my research. In this sense, it gives me satisfaction to know that one of my books has aroused further interest in the subject and that new interpretations have come out.

The interpretation of facts seems to me to be the most important aspect on which the above-mentioned scholars focused their attention. The same historical reality can be considered from different angles, depending on the historian who analyzes it. Therefore, my interpretations will not always coincide with those of my critics. To begin with, it was indicated that I do not write intellectual history, properly speaking, but rather that I am preoccupied with the formulation of a philosophy of the history of America. José Gaos had already pointed this out to me, though not in a critical way. In contrast, William $\mathrm{D}$. Raat directly and concisely criticizes my focus on historical reality, which preoccupies both of us. He says, "For Zea, the importance of his work on positivism is found in relation to a larger context and concern, that of the philosophy of the history of the New World." What is the reason for this concern? Raat answers:

Now the Mexican as an American can universalize from his particular Mexican situation to develop a New World philosophy which 
can be shared with all humanity. American philosophy will save Occidental culture from the spiritual crisis of our times and turn the tide of dehumanization.

This, then, is Zea's grand scheme and hope for the future. It has been argued that philosophy of history is poor philosophy and bad history. All I can claim is that in the final analysis Zea's speculation about history is beyond the realm of ordinary historical analysis. It is metahistory, not intellectual history. ${ }^{1}$

Charles A. Hale, on the other hand, maintains that "the North Americans consider the presuppositions from which the Mexicans depart to be entirely different from those that should be made by a historian in the strict sense of the word. . . . What makes Zea's work unsatisfactory from a historiographical point of view is the impossibility of separating the philosopher from the historian."2 Harold Eugene Davis accepts Zea's metahistorical preoccupation in a broader sense, even though he has not accepted his interpretation. He says, "We owe a large debt to Zea for his interpretation of the nineteenth century, even while not accepting all of Zea's dialectic."3

Where is the problem? According to what we have said, it would be in the scholar's situation or historical perspective. From this viewpoint it seems that my colleagues in the United States feel that they can write a history that is not their own more objectively and that they are less apt to fall into the same snares as those who interpret their own reality. Zea's philosophical suppositions, says Hale, "impose certain limitations on the reliability of his work as intellectual historian. If the historian must become totally involved in the past, and if his principal concern is the future, how can he help but distort the historical matter he is studying." And Raat says, "Unwilling to detach history from present or future concerns, viewing his role of a philosopher-savior who will direct Mexico's destinies toward a genuine historical con-

1 William D. Raat, "Ideas and History in Mexico: An Essay on Methodology," in Investigaciones contemporáneas sobre historia de México, p. 696.

2 Charles A. Hale, "Sustancia y método en el pensamiento de Leopoldo Zea," Historia Mexicana 20 (October-December 1970): 286, 301.

3 Harold Eugene Davis, "La historia de las ideas en Latinoamérica," Latinoamérica anuario de estudios latinoamericanos, vol. 2.

4 Hale, "Sustancia y método en el pensamiento de Leopoldo Zea," p. 300. 
sciousness in the Hegelian sense, Zea's subjective histories invite honest criticism." This is a difference in interpretation, which both Hale and Raat will end by presenting as a difference in methods. This is a point of departure for a criticism of North American scholars, for it appears that some have accepted this philosophical interpretation. North and Latin Americans are invited to reconsider both their viewpoints and their method of interpretation so that they can write a more objective intellectual history of Latin America.

It is in relation to this supposed objectivity, not contaminated by historicism, sociology of culture, and other philosophies, that the method of Arthur Lovejoy is presented as an example. Raat says: ". . . historical understanding requires transcending the biases of the present. . . . The task of the historian was not to bring certainty, but to approximate objectivity." For Lovejoy, "to confuse a present idea with the past events to which it refers violated the basic canons of temporalism."6 Hale, however, although in passing, refers to the impossibility of a similar interpretation among Latin American and United States historians. He admits that the latter have more of a possibility for objectivity because United States historians are farther away from the problem peculiar to the Latin American historian of Latin American ideas, as in my own case. Foreign historians have no limitations regarding nationality. He says: "Here the foreign historian has an opportunity that is unique and worth mentioning. Inasmuch as he is not directly affected by patriotic sentiments, he probably has greater freedom to relate ideas to their proper historical perspective. . . . In other words, perhaps it is easier for the outsider to make a critical and comparative study than it is for the native historian."

Thus, regarding the objectivity of United States historians of their own history, great as well as lesser known ones, we simply would have to cite Albert $\mathrm{K}$. Weinberg's book Manifest Destiny, in which he expounds on the philosophy of United States history that has to justify the expansion of that country at the expense of other peoples. Latin America is necessarily part of that world which he includes in his history.

5 Raat, "Ideas and History in Mexico," p. 694.

6 Ibid., p. 697. 
With respect to Latin American historians, they would have to refer to the history of the 'United States, and therefore it would be difficult for them to maintain the objectivity that United States historians supposedly have when they write about Latin America. When the Latin American historian writes about the United States, he must refer to the present, past, and future of his own history, making impossible the objectivity required of the historian. Hale mentions this lack of objectivity when he refers to my work: "The United States represents for Zea the 'simplistic' modernity which has even relegated Europe to the status of marginality attributed to the Hispanic world. Yet, there is still an ambivalent note in Zea, for it appears that his fundamental antagonism toward the United States is not toward its values per se, but toward North American imperialistic resistance to the realization of these values by other peoples."

Now the question with respect to the objectivity of United States historians toward Latin America must be inverted. The opposite, we insist, is practically impossible for Latin Americans, because the history of Latin America is deeply immersed in the history of the United States. Thus, in my books América como conciencia, América en la historia, and Dialéctica de la conciencia americana, I have insisted on giving the word dialectic two different meanings, the Latin and the Saxon, to define this unavoidable relationship. Thus, does it mean that a United States historian of Latin American intellectual history cannot relate Latin American history to his own if he wants to be objective? Would not such supposed objectivity be the best expression of this unavoidable interdependence? Would not such a relationship also explain the concern about supposed contagion that some United States historians of Mexico and Latin America suffer by accepting the interpretations of their Latin American colleagues? The criticism to which we have referred, the need for a more objective methodology, originated in this concern. Harold Eugene Davis says, "A number of North American scholars, consciously or unconsciously, were inspired to write on Latin American positivism in Zea's

\footnotetext{
302.

7 Hale, "Sustancia y método en el pensamiento de Leopoldo Zea," pp. 297,
} 
terms."8 Mexican historians of positivism since Zea have been, says Raat, with a few exceptions, dependent upon Zea's methodologies. "English-speaking writers have shown even less inclination than their Mexican counterparts to question Zea's method and conclusions." It is precisely a matter of seeing history more objectively, free from presentism and futurism. It would mean the revision of a study that is considered the only one of its kind in this period. But, let us repeat the question. Can the United States scholar separate his own history from the history of Mexico and Latin America? Can he obtain objectivity without falling into futurism and without justifying his own relations with Latin America?

Characteristic of the problem of objective comprehension is one of the criticisms of the pivotal interpretation of all my works, including my philosophy of positivism in Mexico. Charles A. Hale points out two tendencies in my work: On the one hand, he says, Zea appears as a liberal, interpreting Latin American history as a progressive effort toward the "mental emancipation" of the Latin American from the Spanish colonial regime; but, he adds, on the other hand, "he is in search of cultural identity in historical reality," which is affirmed in that same past that denies the liberal position. Thus, he is in rebellion against liberalism. He adds, "It is ironic that Zea is in reality looking to the Spanish reform tradition in his search for Latin American cultural identity in the modern world." And elsewhere he says, "Contrary to what Zea thinks, we think it can be demonstrated, for example, that the mental emancipator, José María Luis Mora, was far from rejecting the Spanish heritage. Rather, he was prepared to turn to the inspiration of the Bourbon and Cádiz reformers."10

The key interpretation of my work, including El positivismo en México, concerns the situation and consciousness of man's dependence in Latin America as well as the efforts he has made and is making to end this dependence. In order to complete the desired

8 Davis, "La historia de las ideas en Latinoamérica."

9 William D. Raat, "Leopoldo Zea and Mexican Positivism: A Reappraisal," Hispanic American Historical Review 48 (1968): 3.

10 Hale, "Sustancia y método en el pensamiento de Leopoldo Zea," pp. 288$289,300-301$. 
political emancipation of Mexico, he affirmed the necessity of "mental emancipation" from Iberian colonialism. By accepting positivism, Mexico strove to break completely with its colonial heritage, which had imposed habits and customs that prevented it from becoming incorporated into the world of progress led by England, France, and the United States. The acceptance of positivism was an attempt, as Justo Sierra picturesquely describes it, to Saxonize Mexico, that is, to convert the Mexicans into "Yankees of the South." Something similar was attempted by the Argentinian Domingo Faustino Sarmiento when he proposed a United States of South America. Why did the generation of Justo Sierra wish to make the Mexicans Yankees of the south? One very important reason was to prevent Mexico from again becoming subordinate or dependent. Mexico should not fall under another insatiable colossus of the north.

In other words, to reject one type of colonialism while refusing to accept another is not, nor can it be, contradictory. On the contrary, this is a natural attitude of an association of people, like the Latin Americans, who become conscious of their existence under the emblem of subordination. Liberalism and positivism, as opposed to Iberian colonialism, were instruments to abolish the habits and hereditary customs that prevented Latin America's incorporation into the world in a nonsubordinate way. And opposed to the new type of subordination, which was peculiar to the founders of liberalism and positivism, it was also natural that the Latin American search his own history, denied only as it justified the old dependence, for instruments to prevent the justification of a new kind of colonialism. It was the purpose of the Mexican Revolution to confront this two-fold subordination, that is, the old and the new, or Porfiriato, which sought its justification in positivism. José María Luis Mora was the prototype of this meaning. He repudiated, on the one hand, expressions of the colonial period, such as "mania for holding public office," which created Mexican attitudes of servility, because they prevented Mexico's incorporation with the past. On the other hand, he looked into that same past, which was also Spain's past, for a liberal and reform doctrine of which Spain herself had given great examples. He searched in the past for Iberian values that did not contradict the efforts and desires of the Mexican to become as capable as the Saxon so that he 
could control his natural world and use its wealth as the basis of his own development. He wanted progress that would not be in the hands of foreigners.

The history of positivism in Mexico as well as in Latin America is the expression of an experience that terminates in a dead-end alley. Despite the spirit of this doctrine, and their supposed assimilation of it, Mexicans did not transform themselves into "Yankees of the south." Nor was South America converted into the United States of the south. If one form of subordination was destroyed, another was immediately created by the formation of Latin American societies hardly different from those created by three centuries of Iberian colonialism. A new colonialism was created by nations who were the leaders of progress. Mexican positivists became tools in this new order. Their social preeminence was patterned after Iberian colonial exploitation.

Then where is the contradiction? The attitude is the same for both Mexican and Latin American liberals who tried to abolish colonial habits and customs. They tried to solve the problem with doctrines that they thought might eliminate former feelings of subordination and dependency. They adopted liberal institutions and educated the people to habits of work that would allow Mexico and Latin America to exploit their own wealth. One and the same is the attitude of the Latin American nationalist, who looks to his own past for forms, doctrines, and experiences capable of forging a feeling of unity, and refuses to accept new kinds of subordination, such as becoming an instrument of foreign progress. It is purely and simply a matter of selecting past values that can help realize possible future values. Are we once again falling into a metahistorical interpretation? Of course, if at the same time we accept the impossibility of the objectivity that should be proper to intellectual history.

But how can the same United States historian be objective when he writes about Latin America? Charles A. Hale, like his colleagues who have already been mentioned, explains how this supposed intellectual and objective history of Latin America should be written. This history, he says, "will allow us to surmount the sterile debate over whether Latin American thought is original or imitative. Though it has obsessed Zea and others, it is a debate the outside intellectual historian need not enter into. We can reject 
the distinction between 'Western' and 'Hispanic' and begin with the simple assumption that Latin America, like Spain, has always been intellectually a part of the West. Our question is why certain currents of thought were significant and why others were not."11

Thus, the debate on the originality and imitation of Latin American thought is not, nor can it be, sterile, inasmuch as it concerns the Latin American historian's feelings toward subordination and dependency in his history. For my part, I have looked in the socalled imitation of foreign philosophies for expressions of a certain originality, that is, the form in which these philosophies are applied to problems that are peculiar to Latin America. Another of my concerns is to know Latin America's place in Western culture. Therefore, the central theme of my works is América en la historia.

One of the main concerns of Latin American intellectuals is how their societies can form part of Western culture without accepting dependency. That is why Latin America has incorporated certain aspects of Western thought into its own and not others, trying not simply to repeat them, but to make them a vital part of their own being. This incorporation is expressed as awareness of originality.

Is Latin America part of the West? Relatively, yes, but in what way? It is unwilling to continue to be subordinate to the West or to any other power. This coincides with the struggle of the nonWestern peoples of Asia, Africa, and Oceania, who also struggle like Latin America to become an active part of Western culture, refusing to be its tool by accepting a dependent status. The assimilation of a philosophy peculiar to this culture has always occurred in relation to this concern, which has given rise to the debate mentioned by Hale, a debate which cannot be considered sterile.

Then, can the United States historian, who is an active part of a culture whose values have become universal, maintain objectivity as if he had nothing to do with the extension of those values and with the demand made by non-Western peoples for the recognition of those values in themselves? Is it not this awareness that caused, in the United States, the great moral crisis that now afflicts its people? Are not the people of Southeast Asia fighting for the recognition of those same values? Is this not the essence of the intellectual history of Latin America since its political independ-

11 Ibid., p. 304. 
ence from the Iberian world? The history of the United States, like that of the Western world, is an essential part of the history of Latin America. And it is with reference to this interdependence that problems of dependency and limitation continue to arise. In this sense, cannot United States historians retrace Latin American history as the history of the third-world countries is now being retraced and show the relationship between their history and Latin American history? Is there not a connection between the sense of dependency and underdevelopment and the sense of dominion, colonialism, and development? I understand that such an interpretation would necessarily have to transcend pure historical fact, no matter how objective the world might seem. The past and the present would have to be interpreted in relation to what is desired for the future. Metahistory? Philosophy of history? I do not believe that is important. What is important, however, is a better understanding of the man who makes history, independent of his situation, so that he can transform it.

In concluding this preface, I wish to express my appreciation to Dr. Stanley R. Ross for his interest in the publication of this book in English, as well as to the University of Texas Press, which has made it possible. I am also grateful to my translator, Dr. Josephine Schulte. This subject is one in which she herself is a specialist, as she demonstrated in my seminar entitled "The History of Ideas in Latin America," which was offered in the Department of Philosophy and Letters at the National and Autonomous University of Mexico in 1966, which she attended while she was in Mexico researching certain unstudied aspects of the topic with which this book deals. 
THIS PAGE INTENTIONALLY LEFT BLANK 